\title{
EVALUATION OF USEFULNESS OF THE DESIGNED LABORATORY PHOTOBIOREACTOR FOR MICROALGAE CULTIVATION IN CONTROLLED CONDITIONS ${ }^{1}$
}

\author{
Beata Brzychczyk*, ZbigniewKowalczyk, Jan Giełżecki \\ Institute of Agricultural Engineering and Informatics, University of Agriculture in Krakow \\ "Corresponding author: e-mail:Beata.Brzychczyk@ur.krakow.pl
}

\begin{tabular}{l}
\hline ARTICLE INFO \\
\hline Article history: \\
Received: July 2015 \\
Received in the revised form: \\
October 2015 \\
Accepted: November 2015 \\
\hline Key words: \\
microalgae, \\
algae, \\
photobioreactors, \\
chlorella vulgaris, \\
culture medium \\
\hline
\end{tabular}

\begin{tabular}{l} 
ABSTRACT \\
\hline The objective of the paper was to analyse the use of the designed \\
photobioreactor for freshwater microalgae cultivation in the controlled \\
laboratory conditions. The work covered the design and construction \\
of photobioreactors (PBR) and setting up comparative cultivations of \\
freshwater microalgae chlorelli vulgaris along with determination of \\
the biomass growth intensity for a varied amount of supplied culture \\
medium. It was found out that the constructed PBR may be used for \\
microalgae cultivation in the controlled conditions. The impact of the \\
culture medium amount on the growth of chlorelli vulgaris was \\
proved. As a result of the increase of culture medium concentration to \\
$30.1-120.4 \mathrm{ml} \cdot \mathrm{l}^{-1}$ of water, dry mass in photobioreactorsincreased \\
respectively from $1.33 \mathrm{~g} \cdot \mathrm{dm}^{-3}$ to $4.68 \mathrm{~g} \cdot \mathrm{dm}^{-3}$.
\end{tabular}

\section{Introduction}

Microalgae are eukaryotic, photosynthesising microorganisms which are characterized by a simple cell construction and adaptation to variable environmental conditions (Mata et al., 2010). They constitute a group of autotrophic tallophyta, which live in the aquatic or humid environment. They represent the oldest live forms. They have the fastest growth rate and the lowest requirements and ability to bind carbon dioxide. Microalgae constitute a good source of biomass, e.g. for production of biofuels because their growth cycle is shorter than in case of oil plants and they have a higher yield (Spolaore et al., 2006; Wądrzyk and Jakubiec, 2011; Zabochnicka-Świątek et al., 2011). The content of fats in some species may even reach $40 \%$ of dry mass ( $\mathrm{Li}$ et al., 2008). Moreover, they are more easily genetically modified in order to increase the content of lipids (Shaikh A. Razzak et al., 2013; Chisti, 2007). There are microalgae species which have ten times higher yield of biooil than typical oil plants. The time needed to obtain fat and oil fraction from algae takes 3-5 days at the average, while from oil plants -3 months to 3 years are necessary to produce oil (Schroeder et al., 2013).

1 This Research was financed by the Ministry of Science and Higher Education of the Republic of Poland 
Except for biofuel production microalgae have an effective feature consisting in their wide application in the environmental engineering, which enables rational and sustainable use of natural resources. Cultivation of microalgae constitutes an attractive alternative to $\mathrm{CO}_{2}$ sequestration, the source of which are all systems which produce heat and energy. Photosynthesising microorganisms are also used in bioremediation processes of aquatic environment. (Schroeder et al., 2013;Wądrzyk and Jakubiec, 2011).On account of a high content of many macro and micro elements after use they constitute a precious fertilizer. Active biological compounds included therein, constitute a useful concentrate for production of biological feed and supplementation additions (Tuhy et al., 2012). Due to biosorption processes of metal ions, algae enable the increased assimilability of microelements in the feeding process (Chojnacka et al., 2009; Michalak and Chojnacka, 2010; Zielińska et al., 2007).

Microalgae are cultivated in two systems: in the open system and in the closed one (lighted with artificial or natural light). The open systems include lakes, lagoons, ponds and reservoirs. The closed ones include various types of reactors. In order to ensure an appropriate degree of stirring and to avoid unfavourable phenomenon of biomass sedimentation on the bottom, both the open and closed systems are equipped with stirring systems or with recirculation loops. The open cultivation systems have simple construction, are relatively easy to operate and are characterised with low investment and exploitation expenditures. On the other hand, low effectiveness of biomass production, low control of cultivation, and the problem of protection against unfavourable impact of environment on cultivation are drawbacks (Shaikh A. Razzak et al., 2013; Maliga. et al., 2010). Bioreactors constitute a foundation for the closed systems. Their task is to ensure optimal conditions for growth of specific cells in the created environment and to control the system. On account of the cultivation type, bioreactors may work continuously, periodically or half-periodically. Periodical reactors may be used only in laboratory work. In production processes, continuous and semi-continuous flow bioreactors in a single or cascade system are used most frequently. Continuous stir-tank reactors, pipe reactors with plug flow and fluidized bed reactors may be distinguished among them. Bioreactors with stirring and aeration are most frequently used. On account of the geometry of the closed system the following may be distinguished: vertical (pipe and cylindrical), horizontal (pipe and flat), stationary and wandering with solar light, in the form of a battery. The general group of bioreactors contains photobioreactors (PBR - PhotoBioReactor) which are equipped with their own lighting system, high efficiency of biomass production per a volume unit in the strictly controlled conditions. (Shaikh A. Razzak et al., 2013; Hehlmann et al., 2011; Maliga et al., 2010). Prices of ready photobioreactors along with controlling and recording devices offered by the companies which construct them are very high. Therefore, a stand comprising two units of photobioreactors, in which algae cultivation was attempted, was designed and made at the Faculty of Production Engineering and Power Engineering of the University of Agriculture in Krakow.

\section{Objective and scope of the study}

The objective of the paper was to analyse the use of the photobioreactor for freshwater microalgae cultivation in the laboratory conditions. The work covered the design, construction of reactors and setting up a cultivation of chlorelli vulgaris in two PBR units, which 
Evaluation of usefulness...

were made at the Institute of Agricultural Engineering and Informatics of the University of Agriculture in Krakow. A single unit of a bioreactor included the following systems: $\mathrm{CO}_{2}$ feeding system, the system of feeding, the system of temperature measurement, $\mathrm{pH}$, lighting system, mixing system. The designed and constructed prototype of a periodical photobioreactor consisted of a cylindrical glass tank with a bottom made of a white $4 \mathrm{~mm}$ thick glass. A diameter of the designed and constructed PBR unit was $0.17 \mathrm{~m}$ and the height was $0.2 \mathrm{~m}$. Geometric parameters were within the optimal values for this type of reactors determined by Wu and Merchuk (2002) and the working volume was $4.0 \mathrm{dm}^{3}$ fig. 1). A cylindrical reactor was placed inside the lighting system. A diameter of the lighting system was $0.25 \mathrm{~m}$ and its height was $0.23 \mathrm{~m}$. A lighting wall comprised 150 electroluminous LED diodes of the total power of $36 \mathrm{~W}$. Small sizes, low energy losses in the form of heat, possibility of regulation of the intensity of the emitted light decided on their use. Additionally, the lighting system was equipped with the regulation system, which comprised: colour and radiation intensity programmer as well as a timer control, which enable changes of lighting parameters of the cultivation within a wide scope and varied combinations. In order not to limit the growth rate of algae cultures with the light availability as a result of absorption and mutual shading of cells a pump was installed in the reactor. It forces circulation of the cultivation with a manual control of flow depending on the biomass thickness. Stirring and circulation, which can be significantly translated into the amount of conversion of the available light, additionally ensured a regular access to dietary components and prevented thermal stratification of the culture.

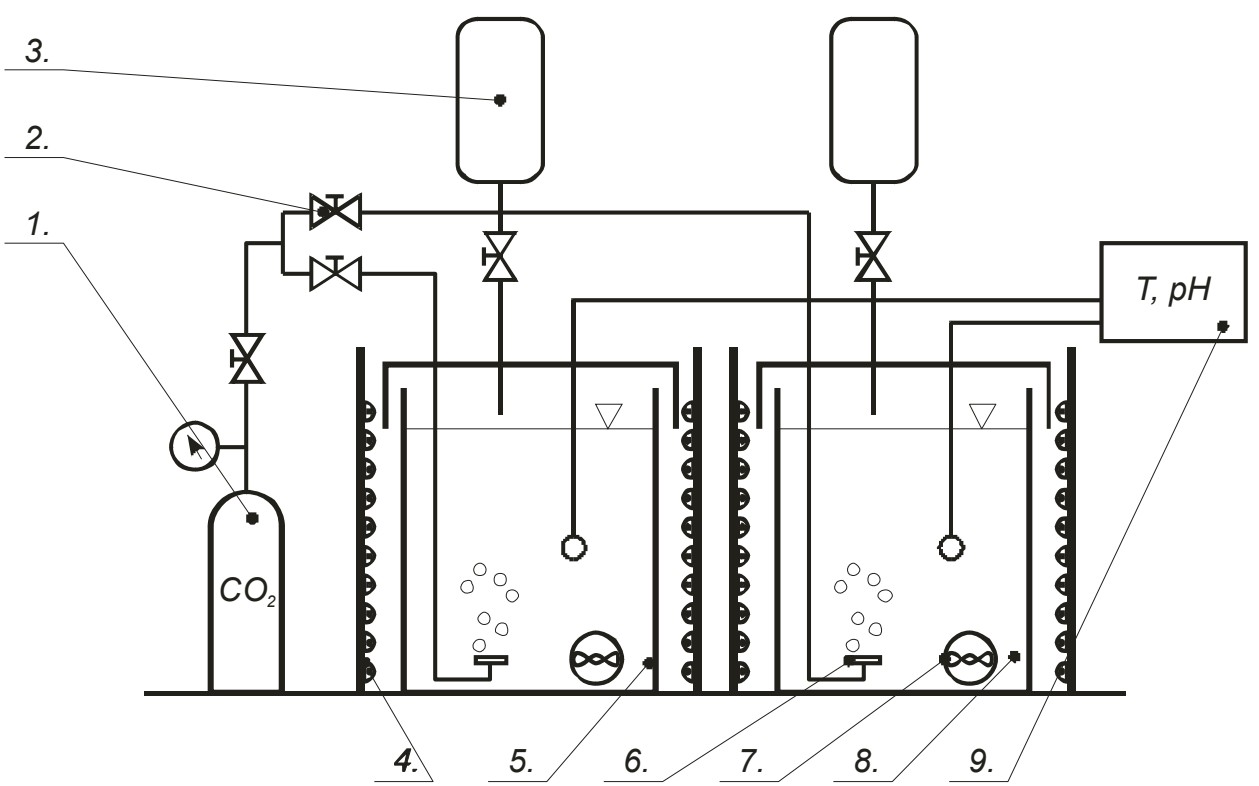

Figure 1. Schematic representation of the research stand $\left(1-\mathrm{CO}_{2}\right.$ tank with control and measuring system; 2 - control valves; 3 -feed tank with a dosing system; 4 - cylindrical lighting wall; 5 -reactor reservoir; 6 - ceramic diffuser; 7 - mixing pump; 8 -cultivation medium; 9 - measuring system) 
Beata Brzychczyk, ZbigniewKowalczyk, Jan Giełżecki

The feeding system comprised a $\mathrm{CO}_{2}$ cylinder with a reducer and an electro-valve. A carbon dioxide was directly introduced to the cultivation with the use of a ceramic diffuser. $\mathrm{pH}$ and temperature were measured with a multi-parameter measuring device. The remaining, control and pilot tests of parameters in the PBR were carried out with the use of calorimetric assays with the use of environmental tests VISOCOLOR $® E C O$ dedicated for determination of surface waters and sewage parameters.

\section{Methodology of research}

Material consisting of algae chlorelli vulgaris, code BA0002a, was obtained from the Culture Collection of Baltic Algae at the Institute of Oceanography of the University of Gdańsk and was inoculated into two tanks of photobioreactors. During the tests, an image documentation of the cultivated algae was made with the use of the Motic Red 233 biological microscope. Figure 2 presents an exemplary image of chlorelli vulgaris magnified by 400 times and figure 3 includes the image magnified by 1000 times (immersion).

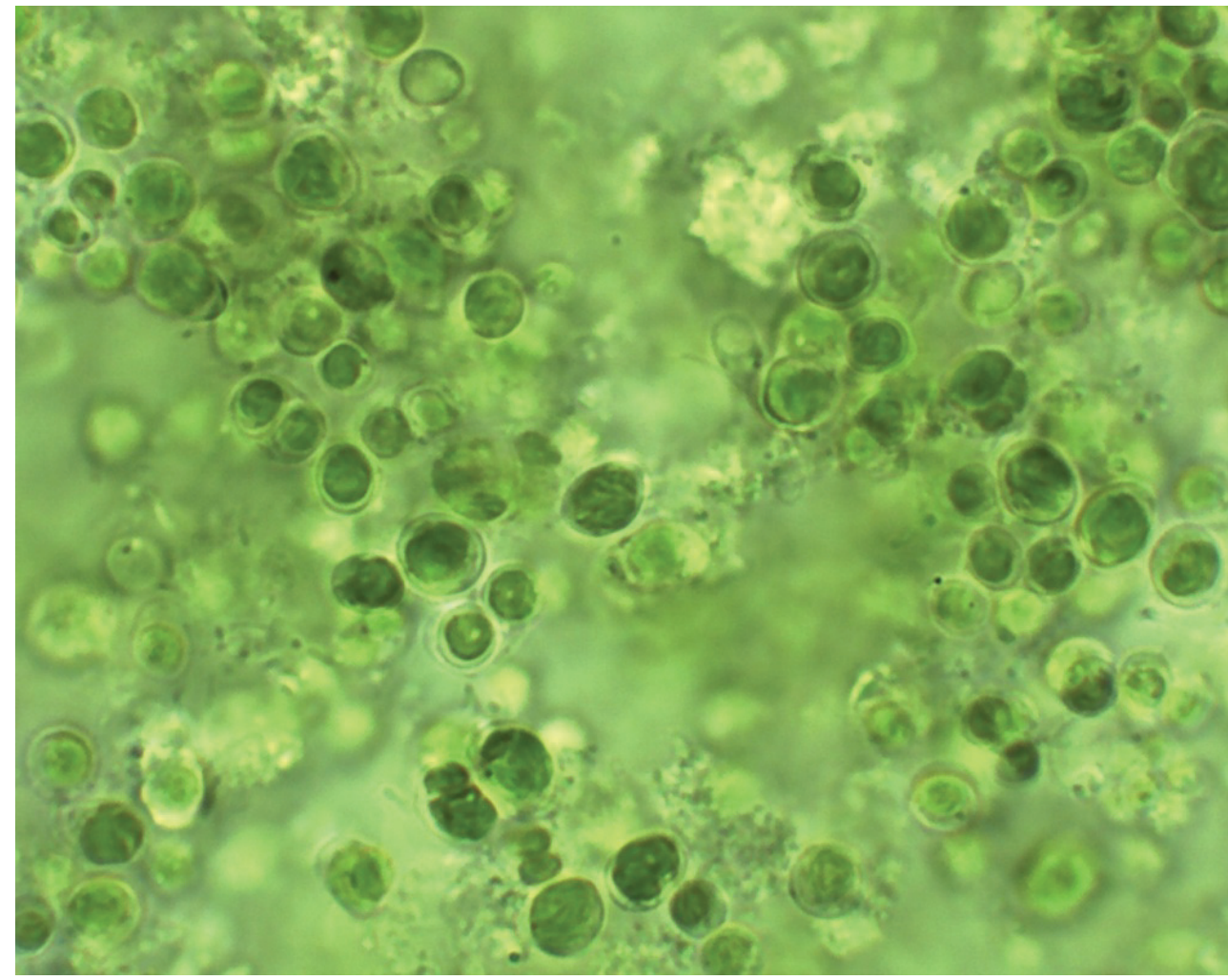

Figure 2. Chlorella vulgaris, magnification $400 x$ 


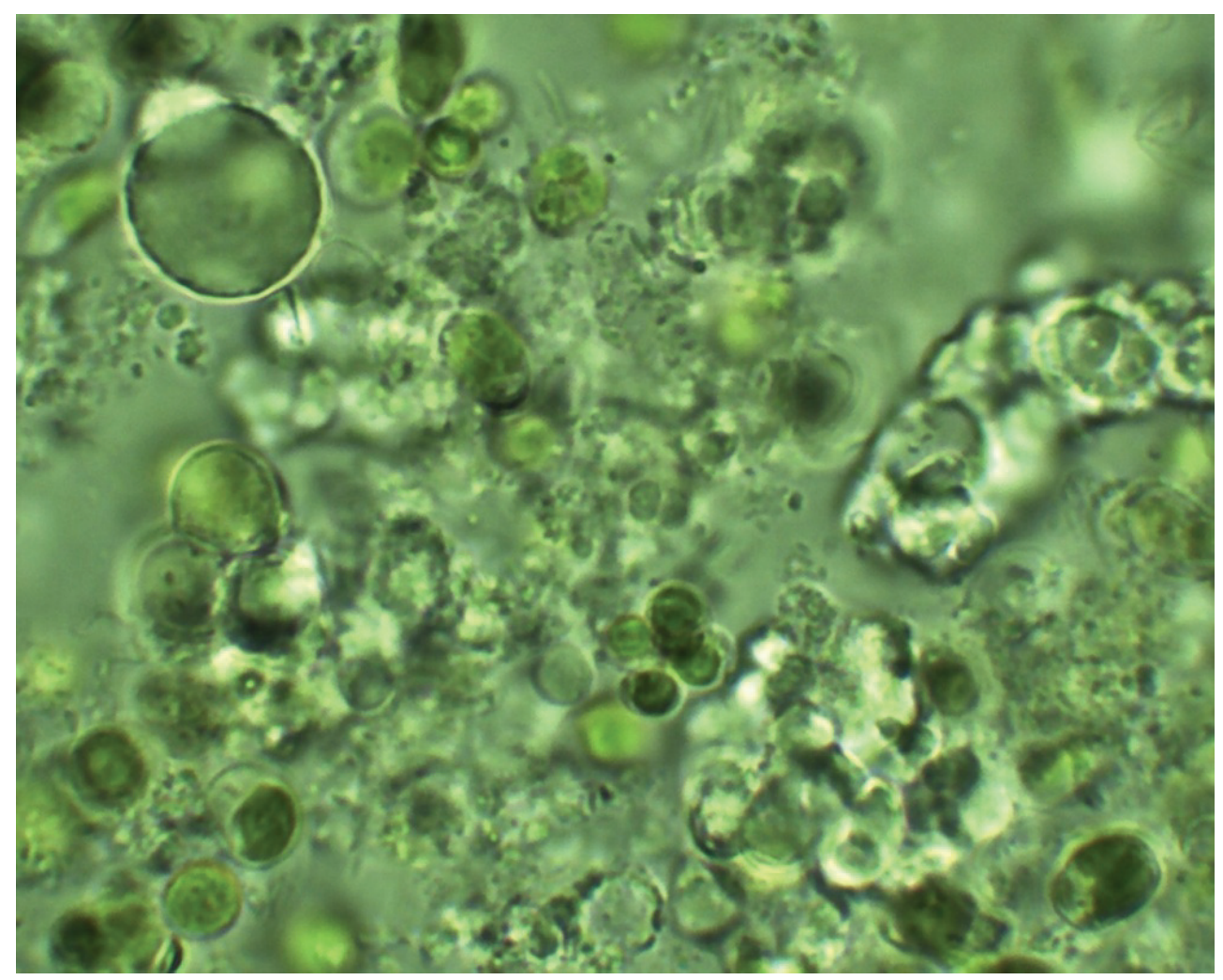

Figure 3. Chlorella vulgaris, magnification 1000x (immersion)

Motic Images Plus 2.0 software enabled measurements of average mature cells of cultivated algae, whose average value was determined within $10 \mu \mathrm{m}$ to $12 \mu \mathrm{m}$ (fig. 4).

During pilot tests on the possibility of using the designed photobioreactors for cultivation of microalgae, two experiments were carried out on the relation of the biomass growth to the type of the used culture medium. Experiments were carried out in 21-day cycles in both BPB units simultaneously at setting identical lighting and temperature conditions. Temperature of cultivation was within $28^{\circ} \mathrm{C}$ to $32^{\circ} \mathrm{C}$ in both units. Cultivation was lighted in a 12-hour cycle (12/12) at the constant circulation of biomaterial in the reactor. In a 12-hour cycle, $\mathrm{CO}_{2}$ feeding was programmed to carry out the carbon dioxide feed process only in the light phase. Constant $\mathrm{pH}$ cultivation was maintained at the $7^{\text {th }}$ to 8 th level by regulation of the amount of the fed $\mathrm{CO}_{2}$. Culture medium was supplied one time daily in the amount of $50 \mathrm{ml}$. The culture medium composition is presented in table 1 . 
Beata Brzychczyk, ZbigniewKowalczyk, Jan Giełżecki

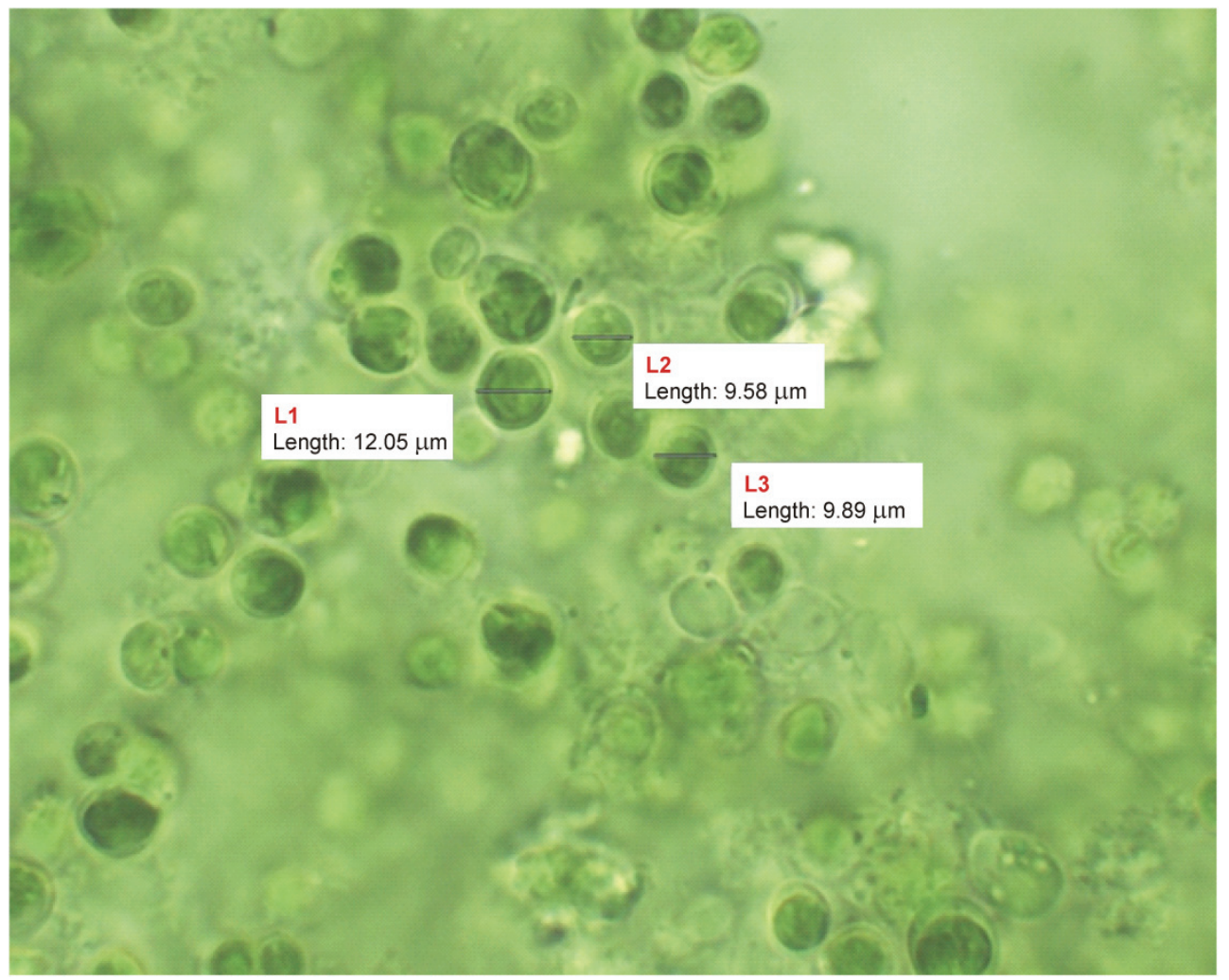

Figure 4. Chlorella vulgaris, measurement of the diameter of mature cells, magnification by $400 x$

Table 1.

Composition of culture medium

\begin{tabular}{lccc}
\hline Element & $\begin{array}{c}\text { Culture medium A, } \\
\left(\mathrm{mg} \cdot \mathrm{dm}^{-3}\right)\end{array}$ & $\begin{array}{c}\text { Culture medium B, } \\
\left(\mathrm{mg} \cdot \mathrm{dm}^{-3}\right)\end{array}$ & $\begin{array}{c}\text { Culture medium C, } \\
\left(\mathrm{mg} \cdot \mathrm{dm}^{-3}\right)\end{array}$ \\
\hline Ammonia nitrogen & 10.80 & 21.60 & 43.20 \\
Nitric nitrogen & 28.45 & 56.90 & 113.8 \\
Amide & 22.68 & 45.36 & 90.72 \\
Phosphorus pentoxide & 43.12 & 86.24 & 172.48 \\
Potassium oxide & 64.68 & 129.36 & 258.72 \\
Boron & 0.11 & 0.22 & 0.44 \\
Copper & 0.02 & 0.04 & 0.08 \\
Iron & 0.02 & 0.04 & 0.08 \\
Manganese & 0.11 & 0.22 & 0.44 \\
Molybdenum & 0.01 & 0.02 & 0.04 \\
Zink & 0.02 & 0.04 & 0.08 \\
\hline
\end{tabular}


Evaluation of usefulness...

The experiment assumed a pilot cultivation on a culture medium with a varied composition. In order to evaluate the course of the set up cultivation the changes of the biomass growth were being observed after the culture medium A and B were supplied. In the following experiment, biomass production on the culture medium $\mathrm{A}$ and $\mathrm{C}$ were compared. Evaluation of the biomass increase was made once daily by determination of the dry residue of the remaining material by an oven-drying method in the temperature of $105^{\circ} \mathrm{C} \pm 2^{\circ} \mathrm{C}$ for $90 \mathrm{~min}$.

\section{Research results}

The growth of microorganisms in the modelled environment is a complex process influenced by many factors. For description of the growth kinetics and changes which take place during cultivation, only the data which are the most significant or known in time are applied. The process of biomass formation is a chain of complex and mutual relations during which products of changes are eliminated (Schleger, 2003). On the example of the obtained diagrams, the fundamental phases of periodical cultivation may be initially distinguished: stress phase, logarithmic growth phase, cultivation stabilization phase and dying phase. Stress phase (at the average 3 days) i.e. of the time of adjusting to new conditions was a phase of the beginning of cultivation. After this phase, a sudden increase of biomass lasting from 4 to approximately 18 days, depending on the cultivation conditions, took place. Afterwards, the stopping phase took place, after which the further experiment was stopped due to the lack of biomass increase (figure 5 and 6 ). Kinetics and length of particular phases seems to be correlated with cultivation environment parameters.

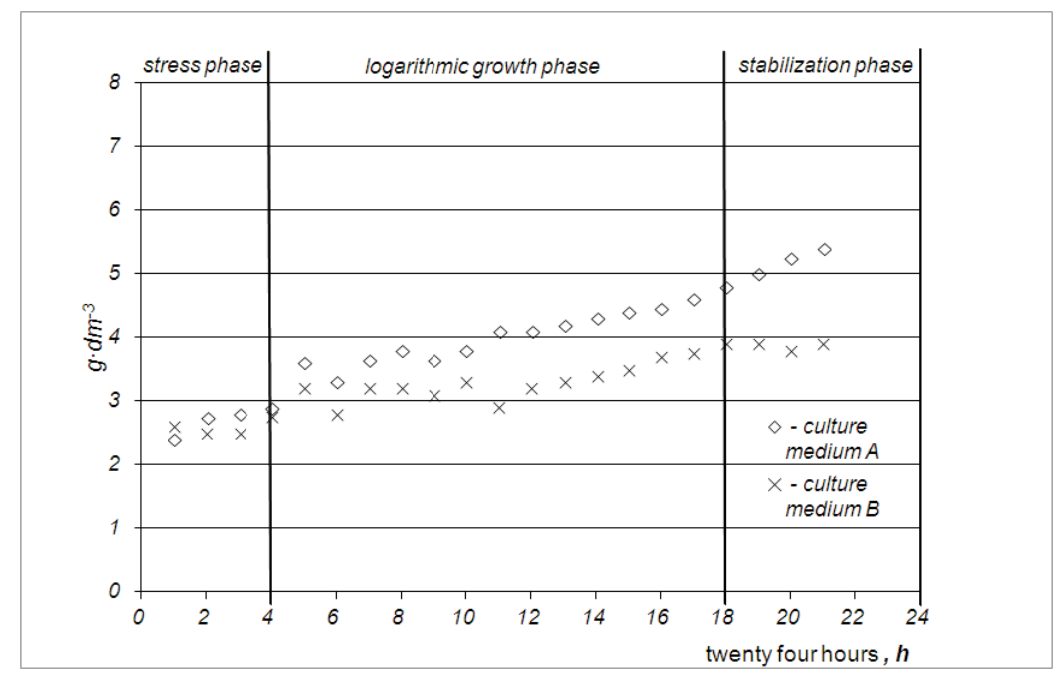

Figure 5. Dry residue - experiment No.1 


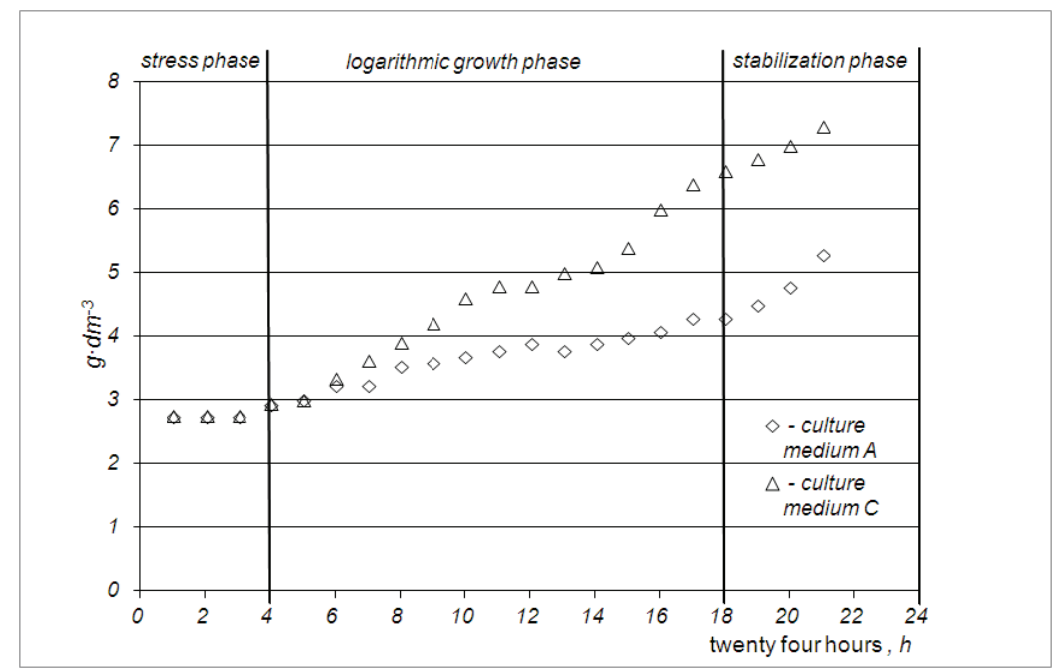

Figure 6. Dry residue-experiment No. 2

When the experiments were initiated, the biomass content in dry residue was within $2.47 \mathrm{~g} \cdot \mathrm{dm}^{-3}$ to $2.71 \mathrm{~g} \cdot \mathrm{dm}^{-3}$. Daily changes of the biomass amount (fig. 5 and 6 ) show that algae increase depended on the supplied culture medium and took place considerably faster in PBR to which culture medium with a higher concentration was supplied. Microalgae cultivation on the culture medium A was by $22 \%$ higher in dry residue in comparison to the culture medium $\mathrm{B}$, poorer in dietary components. On the other hand, biomass growth on the culture medium $\mathrm{C}$ was more efficient by approximately $27 \%$ in comparison to biomass supplied additionally with the culture medium A and by approximately $54 \%$ in comparison to algae cultivated on the culture medium $\mathrm{B}$ at the same time. The highest biomass increase reported for the culture medium $\mathrm{C}$ was $7.28 \mathrm{~g} \cdot \mathrm{dm}^{-3}$.

\section{Conclusions}

Based on the research which was carried out, the following conclusions can be formulated:

1. The designed and constructed photobioreactors can be used for microalgae cultivation in the controlled laboratory conditions and may be an alternative solution for very expensive sets offered by the companies which deal with construction of this type of apparatus.

2. The pace of microalgae growth was expressly related to the concentration of the dosed culture medium. As a result of the increase of culture medium concentration (30.1 to 120.4$) \mathrm{ml} \cdot \mathrm{l}^{-1}$ of water, the dry residue in photobioreactors $t$ increased respectively from $1.33 \mathrm{~g} \cdot \mathrm{dm}^{-3}$ to $4.68 \mathrm{~g} \cdot \mathrm{dm}^{-3}$. 
Evaluation of usefulness...

3. Further research which would allow optimal conditions of microalgae development in the designed and constructed photobioreactors, which would ensure their maximum growth, is necessary.

4. Based on the obtained plots, growth curve of chlorelli vulgaris divided into particular phases may be observed. It was found out that in order to obtain an assumed cultivation in the growth stabilization phase, biomass material for further treatment should be collected improving at the same time, environmental conditions of the remaining culture and to dissolve metabolites of physiological processes with fresh culture medium.

\section{References}

Chisti, Y. (2007). Biodiesel from microalgae.Biotechnology Advances, 25, 294-306.

Chojnacka, K., Górecki, H., Zielińska A., Michalak I. (2009). Technologia wytwarzania biologicznych dodatków paszowych z mikroelementami na bazie alg. Przemyst Chemiczny, 88, 634-639.

Hehlmann, J., Merta, H., Jodkowski, M. (2011). Stereomechanika w budowie aparatów i urządzeń procesowych w: Aparatura procesów chemicznych, biochemicznych i ochrony środowiska tom II, Gliwice, Obtained from: http://www.chemiabioorganiczna.polsl.pl/studenci/materialystudenci/ste reomechanika.pdf.

Li, Y., Horsman, M., Wu, N., Lan, C.Q., Dubois-Calero, N. (2008). Biofuels from microalgae. Biotechnol Progress, 24(4), 815-20.

Maliga, G., Składzień, J., Szymków, J. (2010). Sekwestracja ditlenku węgla przez mikroalgi. Inżynieria i Aparatura Chemiczna, 49, 46-47.

Mata, T., Martins, A., Caetano, N. (2010). Microalgae for Biodiesel production and other applications. A review. Renewable and Sustainable Energy Reviews, 14, 217-232.

Michalak, I., Chojnacka, K. (2010). Koncepcja technologii wytwarzania biologicznych dodatków paszowych z mikroelementami na bazie glonów morskich. Przemyst Chemiczny, 89, 486-489.

Renwei, Q., Yong, F. (2010). The direct pyrolysis and catalytic pyrolysis of Nannochloropsissp.residue for renewable bio-oils. Bioresource Technology, 101, 4593-459.

Schlegel, H. G. (2003). Mikrobiologia ogólna. PWN. Warszawa, ISBN 8301139994.

Schroeder, G., Messyasz, B., Łęska, B., Fabrowska, J., Pikosz, M., Rybak, A. (2013). Biomasa alg słodkowodnych surowcem dla przemysłu i rolnictwa. Przemyst Chemiczny, 92(7), 1380.

Shaikh, A., Razzak, Mohammad, M., Hossain Rahima, A., Lucky Amarjeet, S. Bassi, Hugo de Lasa. (2013). Integrated $\mathrm{CO}_{2}$ capture, wastewater treatment and biofuel production by microalgae culturing-A review. Renewable and Sustainable Energy Reviews, 27, 622-653.

Spolaore, P., Joannis, C., Duran, E., Isambert, A. (2006). Commercial applications of microalgae. Journal of Bioscience and Bioengineering, 101, 87-96.

Tuhy, Ł., Witkowska, Z., Agnieszka Saeid, A., Chojnacka, K. (2012). Zastosowanie ekstraktów glonowych w wytwarzaniu nawozów, pasz, żywności i kosmetyków. Przemyst Chemiczny, 91(5), 1031-1034.

Wądrzyk, M., Jakóbiec, J. (2011). Proces pirolizy mikroalg jako efektywny sposób pozyskania ciekłego biopaliwa. Actaagrophysica, 17(2), 405-419.

Wu, X., Merchuk, J.C. (2002). Simulation of algae growth in a bench-scale bubble column reactor, Biotechnology and bioengineering, 80(2), 156-168.

Zabochnicka-Świątek, M., Bień, J., Ligienza, A. (2011). Wykorzystanie biomasy mikroalg do produkcji biopaliw plynnych. Referat.Konferencja "Debata o przyszłości energetyki" Wysowa Zdrój.

Zielińska, A., Michalak, I., Chojnacka, K. (2007). Zastosowanie alg w oczyszczaniu ścieków i żywieniu zwierząt. Chemik, 11, 534-543.

Research and paper funded from the Statute Activity 3600/Faculty of Production and Power Energy Engineering/2014. 


\section{OCENA PRZYDATNOŚCI ZAPROJEKTOWANEGO FOTOBIOREAKTORA LABORATORYJNEGO DO HODOWLI MIKROGLONÓW W KONTROLOWANYCH WARUNKACH}

Streszczenie. Celem pracy była analiza możliwości wykorzystania zaprojektowanego fotobioreaktora do hodowli mikroglonów słodkowodnych w kontrolowanych warunkach laboratoryjnych. Zakres prac obejmował projekt i wykonanie fotobiorekatorów (PBR) oraz założenie hodowli porównawczych mikroglonów słodkowodnych chlorelli vulgaris wraz z określeniem intensywności przyrostu biomasy dla zmiennej ilości dostarczanej pożywki. Stwierdzono możliwość zastosowania zbudowanych PBR do hodowli mikroglonów w kontrolowanych warunkach. Wykazano wpływ ilości pożywki na rozwój chlorelli vulgaris. W rezultacie zwiększenia stężenia pożywki od $30,1-120,4 \mathrm{ml} \cdot \mathrm{l}^{-1}$ wody, nastąpił $\mathrm{w}$ trakcie trwania doświadczenia przyrost masy suchej pozostałości $\mathrm{w}$ fotobioreaktorach odpowiednio od $1,33 \mathrm{~g} \cdot \mathrm{dm}^{-3}$ do $4,68 \mathrm{~g} \cdot \mathrm{dm}^{-3}$.

Słowa kluczowe: mikroglony, glony, fotobioreaktor, chlorella vulgaris, pożywka 